\title{
Development and analysis of kinematics of working unit of self-propelled drilling ma-chine
}

\begin{abstract}
Self-propelled drilling rigs are widely used in the underground mining. Their main task is to drill holes in the rocks where explosive charges are to be placed. An important feature of this type of machine is its ability to drill holes according to the blasting parameters defined in the documentation. Precision regarding the hole distribution and angular deviation is crucial for fragmentation of the rocks. This paper presents the results of a kinematic analysis of the working unit of a drilling rig designed for KGHM Polska Miedz S.A. The authors determined the design and construction aspects influencing the accuracy of the drilling boom positioning. The working field of the described system was equal to $45 \mathrm{~m}^{2}$.
\end{abstract}

Key words: drilling rig, boom kinematics, numerical simulation, straight line mechanism

\section{INTRODUCTION}

In the room-and-pillar mining systems of KGHM, the deposit is cut by chambers and belts with a width of approximately $7 \mathrm{~m}$ and a height of up to $5 \mathrm{~m}$. The width of the excavations at the cutting stage is up to $7 \mathrm{~m}$. The height of the excavations in the cutting stage depends on the thickness of the ore seam and operational requirements of the self-propelled machines; it can be up to $4.5 \mathrm{~m} \mathrm{[1,2]}$. Drilling works are performed by specialized self-propelled mining machines and rigs (which are also used in the construction of road tunnels). Their task is to drill holes in the rock where explosive charges are to be situated.
A common feature of these machines is the working unit (or units) placed in the front part on which the boom with the drill is mounted (Fig. 1).

The variety of construction of this type of machine and its equipment results from the specifics of its application. Depending on the type of mine, these machines must meet certain requirements [3]. In the mining conditions, the main criteria for selecting the drilling rigs are the overall dimensions of the machine (length, width, and height), minimum turning radius, and work field of the drill. When the machines are used in tunnel construction, the requirements are mainly focused on the largest possible operating field.

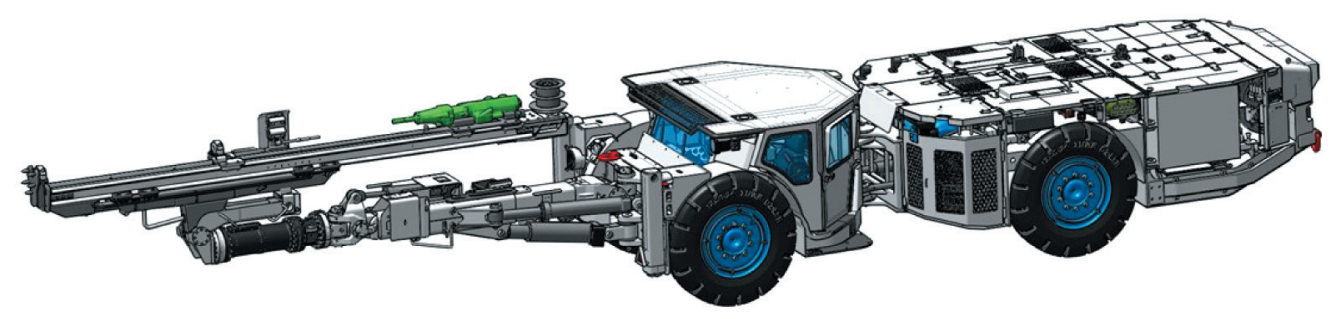

Fig. 1. Mobile mining machine Face Master 1.7L 
Currently, a common requirement for this type of machine is the ability to maintain a parallel direction for all drilled holes in the whole work field, which ensures that the blast holes are made in accordance with a specified metric (automatically or semi-automatic) and, in the case of controlling the working unit by an operator, significantly shortens the time of adjusting the boom relatively to the face $[3,4]$.

This paper presents the methodology and results of work related to the development of the kinematics of the working system of a self-propelled drilling rig with an assumed working area of $8.4 \times 5.6 \mathrm{~m}$, which is adapted to the operational conditions of KGHM [1, 2].

The work was carried out as part of the Smart Growth Operational Program in the project "A new generation of the modular, battery-powered, drilling, and bolting machines designated for operation in underground copper ore mines and mineral resources" (POIR number 01.01.01-00-D011/16), whose aim is to develop, produce, and implement innovative self-propelled battery-powered mining machines for drilling and bolting.

The works include the development of the kinematic system of the working unit, taking into account the operational conditions and technical capabilities of the individual components.

The scope of work included the following:

- structural synthesis of the working unit,

- development of the kinematics of the working unit,

- geometric synthesis of the working unit,

- determination of singular configurations,

- conducting simulation tests,

- determining the working fields along with straight line mechanism errors.

a)

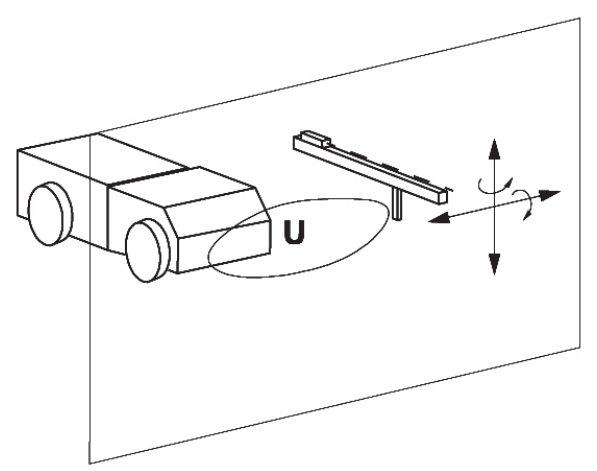

\section{STRUCTURAL SYNTHESIS}

\subsection{Problem identification}

The drilling process requires us to adjust the drill bit at any point in the working field and setting the desired axis orientation of the tool. The basic condition for the drilling rig is moving the drill axis in the working field, which is defined as a fragment of the plane parallel to the face of the machine (Fig. 2a) [3].

From a structural point of view, the working element should have four degrees of freedom $(W=4)-$ displacements along the $\mathrm{Z}$ and $\mathrm{Y}$ axes and rotations around the axes of displacement. Theoretical mobility can generally be written as follows:

$$
W=W_{b}+W_{c}+W_{U}
$$

where:

$W$ - theoretical mobility,

$W_{b}$ - mobility of passive element,

$W_{c}$ - mobility of active elements,

$W_{U}$ - intermediary chain mobility.

Structural synthesis according to Equation (1) can be carried out with different assumptions. Their appropriate selection limits the number of solutions and allows for more simplified choices.

The designated structural scheme is the basis for determining the possible kinematic schemes. The Class II kinematic pair may take different forms. Taking into account the design and operational criteria, the pairs with translational movement were omitted. Guided by the simplicity of the solution, it was assumed that the boom is connected to the body of the machine and to the frame of the drill using universal pairs (Cardan joints). This solution enables us to adjust the drill bit at any point of the working field while maintaining the desired orientation of its axis (Fig. 2b) [3].

Fig. 2. Required degrees of freedom of drill unit frame (a) and kinematic scheme of drilling rig boom (b) 


\subsection{Results of structural synthesis}

The presented kinematic scheme (Fig. 2b) only fulfills the condition of the desired degrees of freedom that the drill frame must have. The operating conditions of the machine cause the fact that a direct imposition of motion in the rotary joint is not feasible. Therefore, the next stage of synthesis is to define the mechanisms that will impose that movement; at the initial stage of the synthesis, these joints will be treated as the active pairs. Due to the high values of the moments, it was assumed that the kinematic input would be achieved through the hydraulic cylinders [3].

The location of the actuator fixing points between the adjacent elements connected by the rotary joint exact the need to increase the overall dimensions of the universal cross pairs. This phenomenon is mainly undesirable for the pairs connecting the boom with the machine body (where high impact forces are acting). The solution to this problem is to increase the space between the axis of the universal pair by replacing the cross with the proper element. An additional advantage of this solution is the fact that the distance between the axes is a parameter that can be selected and, thus, affect the kinematics and strength properties of the working unit.

The full kinematic scheme of the boom mechanism and geometrical conditions after implementing the drive components are shown in Figure 3 [3]. In the case of the actuator re-possible for lifting the drill frame, a different solution was adopted than in other cases. This is due to the fact that this actuator is the only one positioned between adjacent elements forming a rotatory joint. The choice of such a solution was forced by the construction and design aspects.

Assuming the coaxiality of pairs A and D, the mechanisms of lifting the boom and rotator are always in one plane. To obtain a straight-line mechanism in planar motion, triangles $\triangle \mathrm{HBI}$ and $\triangle \mathrm{MGF}$ must always be similar, with the similarity scale is equal to the hydraulic coefficients $W_{p}$ of actuators P1 (HI) and P2 (FM). The dimensions and orientation of these triangles can be arbitrary. This enables us to consider the additional criteria in the process of designing the fixing points such as decreasing stresses, selecting the proper gear ratio angle, avoiding collisions, fostering producibility, or selecting actuators with the standard-sized dimensions. While designing the fixing points of the actuator attachment points, special attention should be paid to the fulfilment of the similarity condition for the minimum length of the real actuators.

$$
L_{\min P 2} \geq W_{p} \cdot L_{\min P 1}
$$

Failure to meet Condition (2) results in a theoretical solution or requires a special manufacturing of the actuator of the lifting of swivel P2. This should proceed in a similar fashion to the case of a turning straight-line mechanism (Fig. 4) [3, 4].

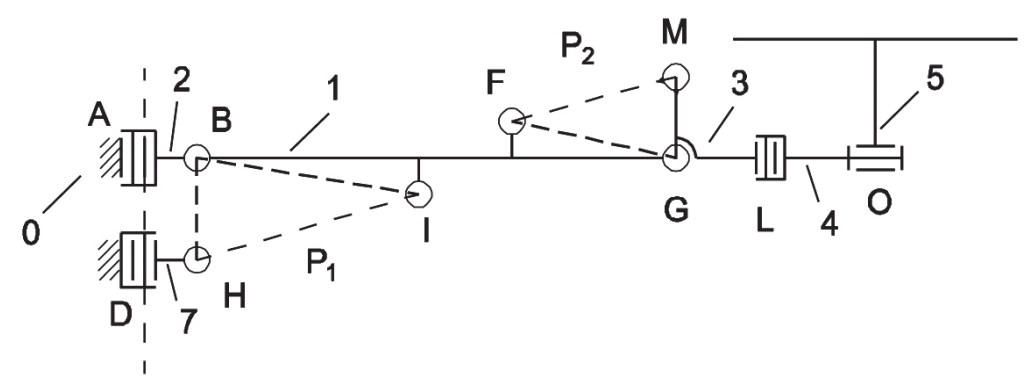

Fig. 3. Kinematic scheme and condition to receive straight-line mechanism for lifting FM 1.7 LE drilling rig

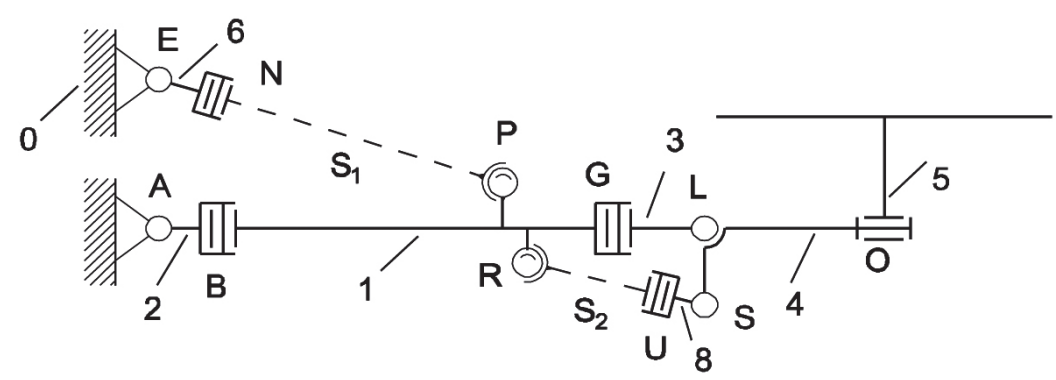

Fig. 4. Scheme of turning straight line mechanism (top view) of FM $1.7 \&$ LE drilling rig boom 
A characteristic feature of the boom turning mechanism is that, when lifting the boom (rotation in Pair B), it rotates around the axis of Pair A. This phenomenon occurs while maintaining the constant length of turning cylinder S1 (Fig. 4). As a consequence, it is impossible to keep the boom axis on one plane while lifting. This situation does not only occur in configurations where the axes of the $\mathrm{B}$ and $\mathrm{N}$ pairs are collinear. Theoretically, there are two such configurations; however, for the structural reasons, none of them exists in the case of designing a turning mechanism.

The reason for why the boom does not take place on one plane (for a constant length of actuator S1) is shown in Figure 5. While lifting the boom, Point $\mathrm{P}$ is on the trajectory being a circle with the radius of BP 'and the center situated on the axis of pair B. Keeping the boom axis within one plane requires that the EP distance changes in a function of boom lifting angle EP $=f\left(\alpha_{p}\right)$. On the other hand, distance EP is the result of the constant length of section EN and actuator S1. It is not possible to comply with both of these conditions for any constant turning angle $\alpha_{S}$. By the appropriate selection of the basic dimensions, this undesirable phenomenon may only be minimized. A similar situation takes place in the case of the mechanism responsible for the relative movement between the rotor and boom.

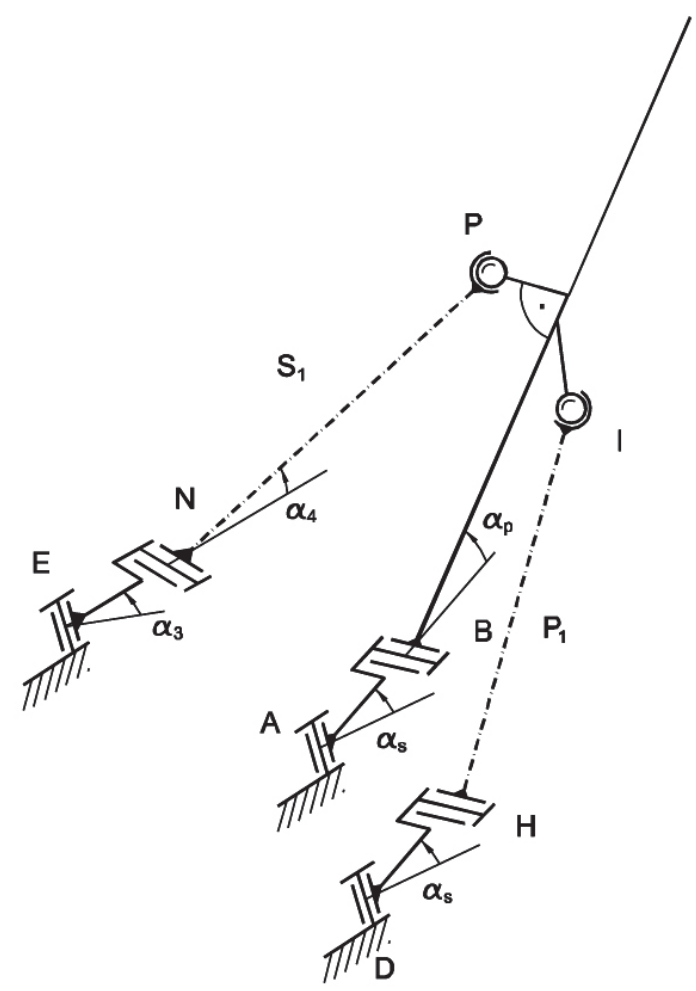

Fig. 5. Spatial kinematic scheme of lifting and turning mechanisms of FM 1.7 LE drilling rig boom
Finally, guided by the limiting of the straightness error criterion and design considerations, the mounting points of the actuators responsible for the boom turning and of the rotator were chosen. The remaining dimensions of the straight-line mechanism were also assumed. In this process, special attention was paid to the kinematic system, which should not reach any singular configurations.

The geometric parameters of the FM 1.7 LE drilling rig (which are specified above) meet all the parameters and design assumptions. As has been shown, the developed turning and lifting straight line mechanisms are not ideal systems due to the accepted technical constraints. They can cause some errors in straightness $\Delta y$ and $\Delta z$ measured in the turning and lifting planes during movement in the assumed work field. Therefore, the determined geometric parameters were verified by numerical simulations in the software for the dynamic analysis of multibody systems such as MSC Adams or LMS DADS.

\section{NUMERICAL SIMULATIONS}

For the purpose of further research, a full simulation model with the turning and lifting actuators of the boom working in the straight-line systems has been built for the developed kinematics of the working unit of the designed FM 1.7 LE drilling rig (Fig. 6) [3]. The LMS DADS system was selected for the simulation. The model was used to investigate the system for the occurrence of the singular configurations to analyze the errors in straightness $\Delta y$ and $\Delta z$ and to determine the exact boundaries of the drilling rig working field.

The elements of the mechanisms during operation may reach positions that are kinematically uncertain. Such positions of the mechanism are commonly either called singular configurations or singular locations. A singular configuration of a mechanical system is one in which the system's behavior cannot be predicted (cannot be determined). The system in the singular position changes its dynamic and kinematic properties (movement ceases to be controlled). The values of some parameters (force, velocity and acceleration) become unknown or approach infinity. Derivatives of the constraint equations of the mechanical system have no solution while being in this position, indicating a mathematical singularity. Near the singular configuration, small modifications in 
a)

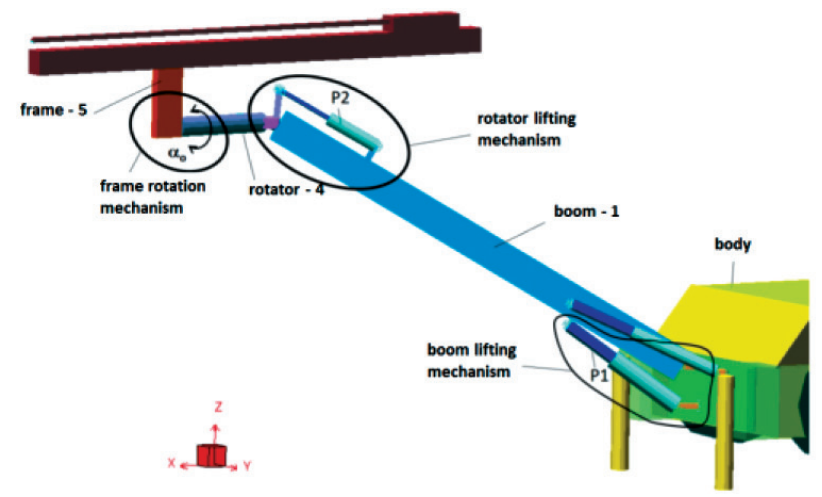

b)

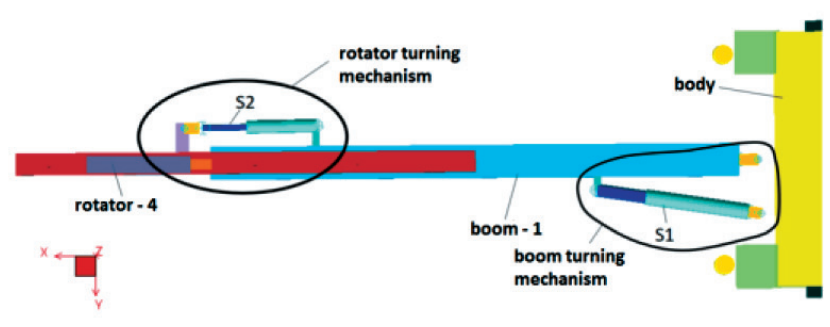

Fig. 6. Solid model of FM 1.7 LE drilling rig: a) boom lifting, rotator lifting, and frame rotation mechanisms; b) top view of model with marked mechanisms of boom and turntable rotation

the input parameters (velocity, force) may cause large changes in the output parameters (or the opposite may occur). In some cases, reaching the singular positions by the elements due to a significant increase in the forces may lead to damage or even the destruction of the system. During its design, singular positions should be taken into account, and the system should not be allowed to reach such configurations. Therefore, one of the widely considered and important design problems is to determine the discussed configuration of the mechanisms and analyze the behavior of the mechanisms in the singular locations. In the developed kinematic system, the dimensions of the elements and drives have been selected in such a way that any singular positions occur for the kine- matics, ensuring the achievement of the assumed work field.

\subsection{Selected simulations results}

The simulation studies of the system allow us to above all determine the real range of movement of the drilling rig and, consequently, determine the actual working field. The parameters that impart motion in the system were the elongation and shortening of actuators P1, P2, S1, and S2 operating in the hydraulic straight-line mechanism. The simulation tests of the boom were carried out while the element was fully extended. The obtained field of work is presented in Figure 7.

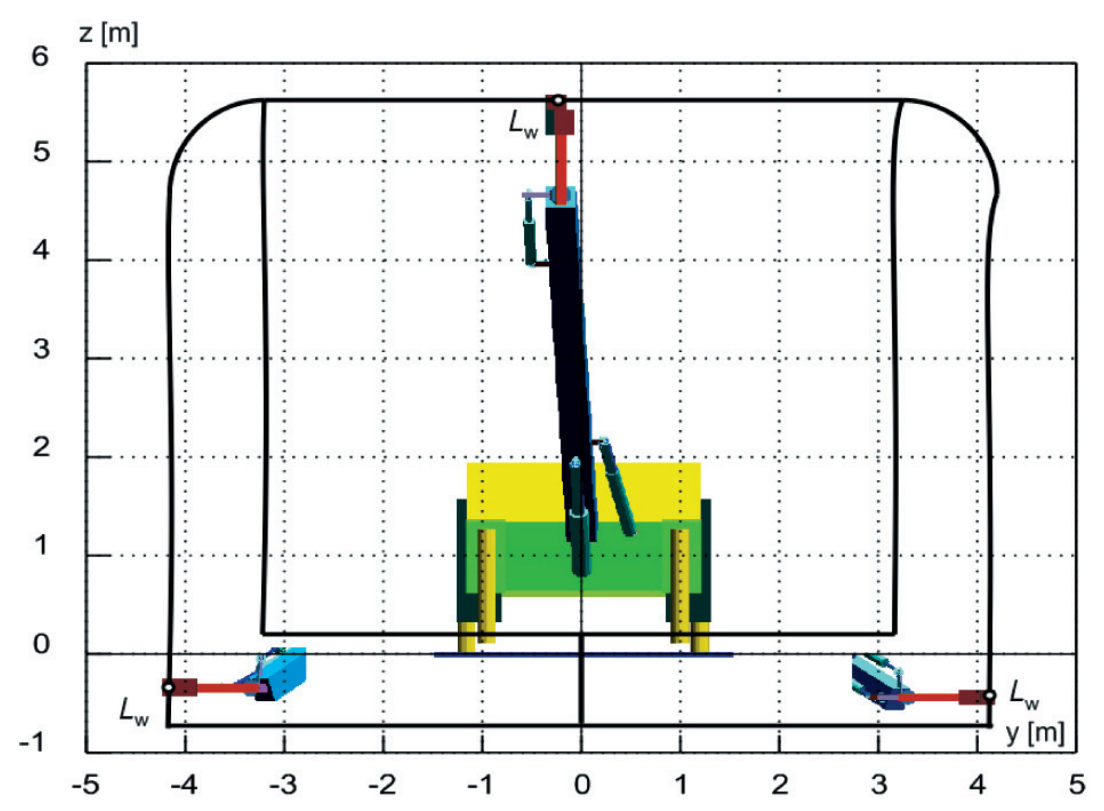

Fig. 7. Total work field of FM 1.7 LE drilling rig determined by three extreme positions of drill: vertical (for rotation angle $\alpha_{o}=0^{\circ}$ ) and horizontal (for rotation angles $\alpha_{o}=90^{\circ}$ and $\alpha_{o}=-90^{\circ}$ ) 
Additionally, an error analysis was performed by simulating the movement of the boom on the selected lines of the work field. In Figure 8, the authors presented the field of operation with the scheme of the lines selected for testing: p-25, p0, p15, p30, p45, s-38, s-19, s0, s19, and s38. In addition, the $P_{i j}$ measurement points $(i=0, \ldots, 5 ; j=1, \ldots, 7)$ have been desig- nated in the working field, and the exact error values have been determined.

An example of the simulation scheme and specification of determined errors $\Delta y$ - turning straight line mechanism, $\Delta \mathrm{z}$ - lifting straight line mechanism, and for motion along the selected horizontal line is presented in Figure 9.

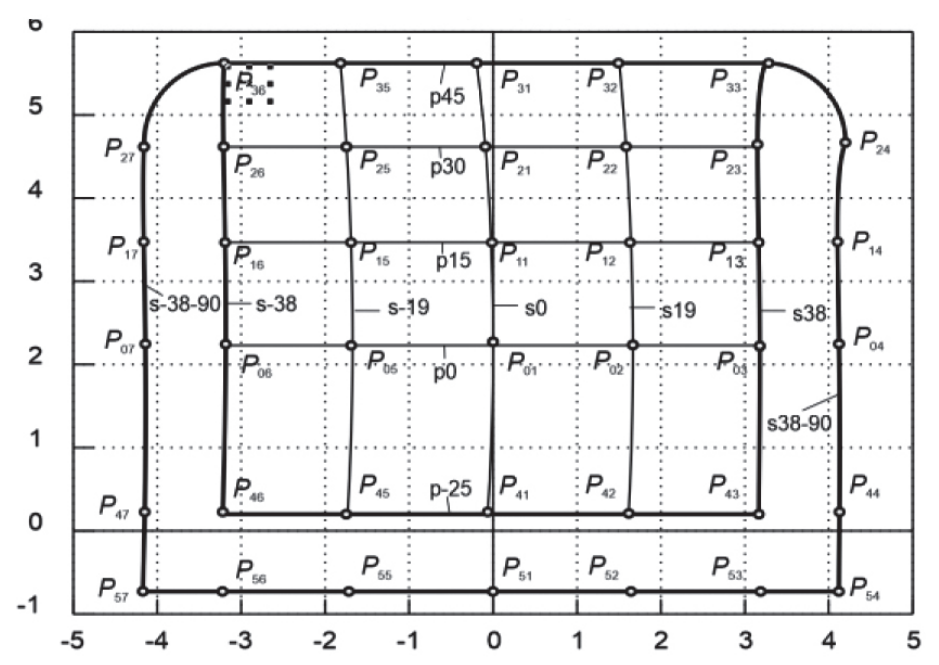

Fig. 8. Front view of operation field of FM 1.7 LE drilling rig with marked sample lines and points $P_{i j}$, where detailed values of straight-line mechanism errors $\Delta z$ (lifting) and $\Delta y$ (turning) were determined

a)
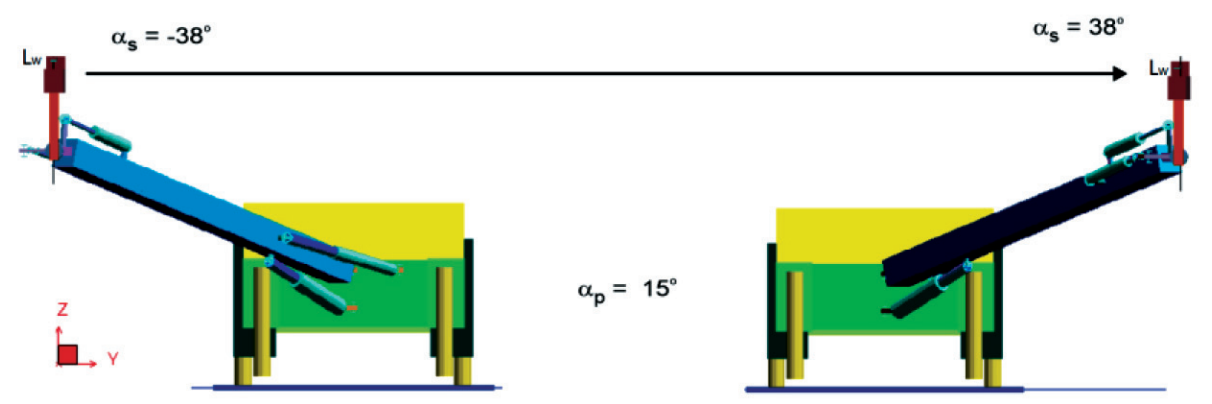

b).

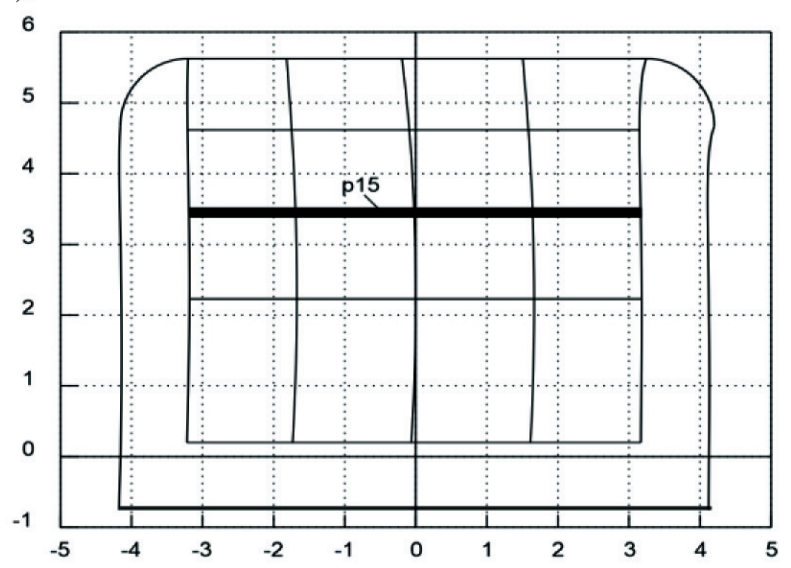

c)

Fig. 9. Study of straight-line mechanism precision while moving frame (point $L_{w}$ ) along $p$-15 line in function of rotation angle $\alpha_{s}\left(-38^{\circ}<\alpha_{s}<38^{\circ}\right)$ extension change of turning actuator with constant lifting angle $\alpha_{p}=-25^{\circ}$ constant extension of lifting actuator); a) simulation scheme; b) line p-15 location; $c$ ) obtained errors of lifting $\Delta z$ and turning $\Delta y$ straight line mechanisms 


\section{CONCLUSIONS}

As a result of the carried-out studies, the structure, kinematics, and geometry of the working unit of a new Face Master 1.7 LE battery-powered drilling machine were developed for a given working field $(\mathrm{H} \times \mathrm{W}-5.6 \times 8.1 \mathrm{~m})$ as well as for the specified lifting and turning angle of the boom.

In the first part of the research, a structural synthesis of the boom mechanism was performed. The aim of the work was to provide the required number of degrees of freedom to the drill. The authors selected a basic scheme of the boom; it allows for the possibility of the drilling rig to operate both when there is a kinematic coupling of the proper pairs of the active elements as well as when they operate completely independent of each other.

In the next stage, a kinematic scheme of the boom was selected, which was then complemented with chains containing active elements (actuators). With the full kinematic scheme, the basic dimensions were defined. While designing the geometry of the boom's kinematic, all assumptions and constraints were taken into account (maximum ranges of motion, type and geometry of the actuators, hydraulic coefficients of the straight-line mechanisms, dimensions of the mounting plate, and type and geometry of the drill frame, rotator, etc.).

The process of defining the basic dimensions has been divided into two phases. The first specified the geometry for the lifting mechanism. In the second step, the dimensions of the turning mechanism were determined. The process of defining basic dimensions was carried out for the assumption that the main task of the drilling rig is working in coupled actuator system.

The primary criterion of the quality of operation of the designed boom straight line mechanism was to maintain a constant orientation of the drill axis at each point of the working field. Unfortunately, fulfillment of the structural requirements entailed the necessity to deteriorate the quality of the obtained straightness of the system. For this reason, the tedious process of designing the dimensions of the kinematic system was necessary. The purpose was to obtain errors in the straightness of the drill axis below $1^{\circ}$.

Finally, the authors obtained the kinematic system of the FM 1.7 LE drilling rig, which reaches the required field of work of the drill.

\section{Acknowledgement}

The research is co-financed by the National Center for Research and Development within the framework of the "A new generation of the modular, batterypowered, drilling and bolting machines designated for operation in the underground copper ore mines and mineral resources" project (no. POIR.01.01.01-00D011/16 in the Smart Growth Operational Program).

\section{References}

[1] Butra J., Dębkowski R., Kosiorowski A., Kosior A.: Sposób wybierania złoża o małej miąższości w strefach ochronnych głównych wyrobisk korytarzowych kopalń rud miedzi, "Rudy i metale nieżelazne" 2004, 49, 6: 272-279.

[2] Grzesiński J.: Doświadczenia kopalni "Lubin” w prowadzeniu eksploatacji w warunkach skrępowanych na przykładzie wybranych filarów oporowych, "Mechanizacja i Automatyzacja Górnictwa” 2007, 9: 46-58.

[3] Bałchanowski K.J., Wudarczyk S., Karliński J.: Opracowanie oraz analiza kinematyki układów roboczych samojezdnych maszyn górniczych o napędzie bateryjnym, "Raporty Wydziału Mechanicznego Politechniki Wrocławskiej” 2017, 100: 77.

[4] Bałchanowski K.J., Szrek J, Wudarczyk S.: Kinematic aspects of the drilling ring boom design, in: Proceedings of the 22nd International Scientific Conference, Kaunas 2017: 27-31.

JACEK KARLIŃSKI, Ph.D., Eng. PAULINA DZIAEAK, M.Sc., Eng.

Department of Machine Design and Research

KRZYSZTOF JACEK BAECHANOWSKI, Ph.D., Eng. SEAWOMIR WUDARCZYK, Ph.D., Eng.

Department of Biomedical Engineering, Mechatronics and Theory of Mechanisms Faculty of Mechanical Engineering Wrockaw University of Science and Technology ul. Łukasiewicza 7/9, 50-371 Wroctaw, Poland \{jacek.karlinski, paulina.dzialak, jacek.balchanowski, slawomir.wudarczyk\}@pwr.wroc.pl 


\title{
Opracowanie oraz analiza kinematyki układu roboczego samojezdnej maszyny wiercącej
}

\begin{abstract}
Samojezdne maszyny wiercace znajduja szerokie zastosowanie w górnictwie oraz w budowie tuneli drogowych. Ich zadaniem jest wiercenie otworów w skale, w których następnie umieszczane sa tadunki wybuchowe. Istotna cecha decydujaca o wtasnościach eksploatacyjnych tego typu maszyn jest możliwość wiercenia otworów strzałowych zgodnie ze zdefiniowana metryka strzałowa. Dokładność rozmieszczenia oraz odchylenie katowe otworów strzałowych decyduje o wielkości zabioru oraz rozdrobnieniu skat. W pracy przedstawiono wyniki analiz kinematyki uktadu roboczego samojezdnej maszyny wiercacej przeznaczonej do prac w kopalniach KGHM Polska Miedź S.A. Określono czynniki konstrukcyjne wptywające na dokładność prowadzenia masztu wiertniczego. Omówiono cechy opracowanego układu roboczego o polu pracy wynoszacym $45 \mathrm{~m}^{2}$.
\end{abstract}

Słowa kluczowe: bezpieczeństwo operatorów, FOPS, ROPS, analiza numeryczna

\section{WPROWADZENIE}

W komorowo-filarowych systemach wydobycia KGHM złoże rozcina się komorami i pasami o szerokości około $7 \mathrm{~m}$ i wysokości do $5 \mathrm{~m}$. Szerokość wyrobisk w fazie rozcinki wynosi do $7 \mathrm{~m}$. Wysokość wyrobisk w fazie rozcinki uzależniona jest od miąższości eksploatowanego złoża oraz wymogów ruchowych pracujących maszyn samojezdnych i wynosi do $4,5 \mathrm{~m}[1,2]$. Prace wiertnicze wykonywane są wyspecjalizowanymi samojezdnymi maszynami górniczymi - wiertnicami, stosowanymi również $\mathrm{w}$ budowie tuneli drogowych. Ich zadaniem jest wiercenie otworów strzałowych w skale, w których następnie umieszcza- ne są ładunki wybuchowe. Wspólną cechą tych maszyn jest umieszczony w przedniej części organ (lub organy) roboczy, na którym osadzony jest maszt wiertniczy z wiertarką (rys. 1).

Różnorodność budowy tego typu maszyn oraz ich wyposażenia wynika ze specyfiki zastosowania tych maszyn. W zależności od typu kopalni maszyny te muszą spełniać określone wymagania [3]. W zastosowaniu w warunkach górniczych głównymi kryteriami doboru wiertnicy są: wymiary gabarytowe maszyny (długość szerokość i wysokość), minimalny promień skrętu oraz określone pole pracy wiertarki. W przypadku zastosowania tych maszyn w budowie tuneli wymagania koncentrują się głównie na możliwie

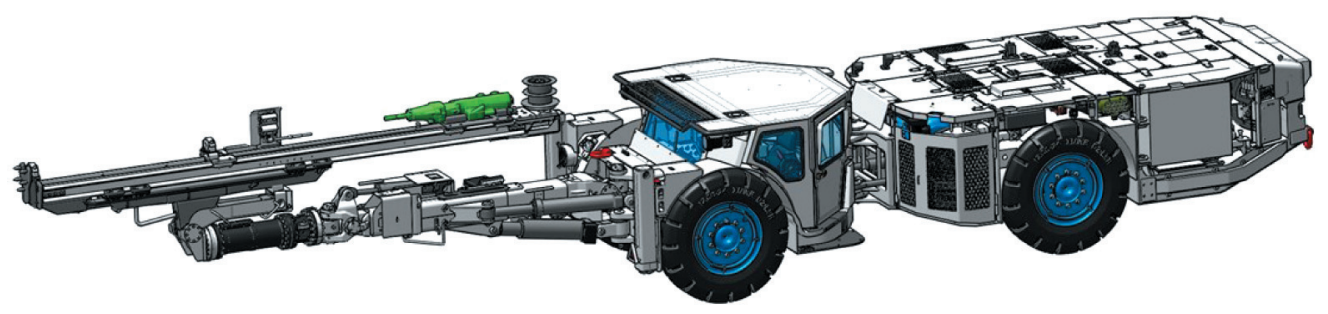

Rys. 1. Samojezdny wóz wiercacy Face Master 1.7L 
szerokim polu pracy. Obecnie wspólnym wymaganiem, dla wszystkich tego typu maszyn jest możliwość utrzymania równoległości dla wszystkich wierconych otworów w całym polu pracy, co zapewnia wykonanie otworów strzałowych zgodnie z określoną metryką, w sposób automatyczny lub półautomatyczny, a w przypadku sterowania organem przez operatora znacząco skraca czas ustawienia masztu względem przodka $[3,4]$.

$\mathrm{W}$ pracy przedstawiono metodologię oraz wyniki prac związanych z opracowaniem kinematyki układu roboczego samojezdnego wozu wiercącego o założonym polu pracy $8,4 \times 5,6 \mathrm{~m}$, który jest dostosowany do warunków eksploatacyjnych KGHM [1, 2].

Pracę wykonano w ramach Programu Operacyjnego Inteligentny Rozwój należącego do projektu pt.: „Nowa generacja modułowych maszyn, wiercącej i kotwiącej, z napędami bateryjnymi, przeznaczonych do pracy w podziemnych kopalniach rud miedzi i surowców mineralnych" nr umowy POIR.01.01.01-00D011/16, którego celem jest opracowanie, wykonanie i wdrożenie innowacyjnych samojezdnych maszyn górniczych $\mathrm{z}$ napędem bateryjnym przeznaczonych do wiercenia oraz kotwienia.

Przeprowadzone prace w swoim zakresie obejmowały opracowanie układu kinematycznego organu roboczego, przy uwzględnieniu uwarunkowań eksploatacyjnych oraz możliwości technicznych wykonania poszczególnych podzespołów.

Zakres pracy obejmowat:

- syntezę strukturalną organu roboczego,

- opracowanie kinematyki organu roboczego,

- syntezę geometryczną organu roboczego,

- wyznaczenie konfiguracji osobliwych,

- przeprowadzenie badań symulacyjnych,

- wyznaczenie pól pracy wraz z wyznaczeniem błędów prostowodów.

a)

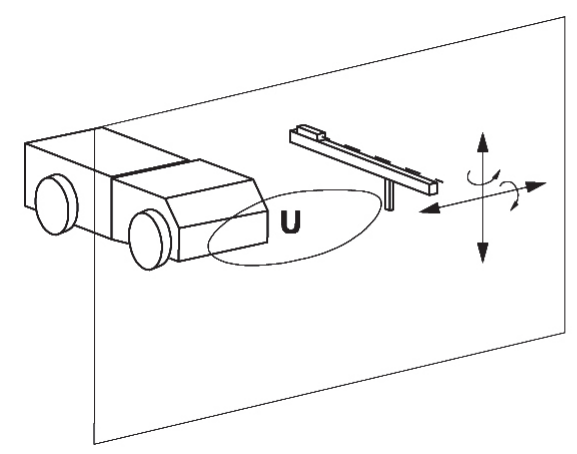

\section{SYNTEZA STRUKTURALNA}

\subsection{Identyfikacja problemu}

Proces wiercenia wymaga ustawienia końcówki wiertła w dowolnym punkcie pola pracy oraz ustawienia żądanej orientacji osi narzędzia. Podstawowym wymaganiem dla pracy wiertnicy jest przemieszczanie osi wiertła w polu pracy, które jest definiowane jako fragment płaszczyzny równoległej do czoła maszyny (rys. 2a) [3].

Ze strukturalnego punktu widzenia element wykonawczy powinien dysponować czterema stopniami swobody $(W=4)$ - przemieszczenia wzdłuż osi z i y oraz rotacje wokół osi przemieszczeń. Ruchliwość teoretyczną ogólnie można zapisać jako:

$$
W=W_{b}+W_{c}+W_{U}
$$

gdzie:

$$
\begin{aligned}
W & \text { - ruchliwość teoretyczna, } \\
W_{b} & \text { - ruchliwość członu biernego, } \\
W_{c} & \text { - ruchliwość członów czynnych, } \\
W_{U} & \text { - ruchliwość łańcucha pośredniczącego. }
\end{aligned}
$$

Synteza strukturalna według równania (1) może być prowadzona przy różnych założeniach. Odpowiedni ich dobór ogranicza liczbę rozwiązań i pozwala na łatwiejszą ich selekcję.

Wytypowany schemat strukturalny jest podstawa do określenia możliwych schematów kinematycznych. Para kinematyczna II klasy może mieć różną postać. Biorąc pod uwagę kryteria konstrukcyjne i eksploatacyjne, zrezygnowano $\mathrm{z}$ par charakteryzujących się ruchem translacyjnym. Kierując się prostotą rozwiązania, wstępnie przyjęto, że wysięgnik połączony jest z korpusem maszyny oraz z ramą wiertarki za pomocą par uniwersalnych (przeguby Cardana). Takie rozwiązanie umożliwia ustawienie końcówki wiertła w dowolnym punkcie pola pracy przy zachowaniu żądanej orientacji jego osi (rys. 2b) [3].

b)

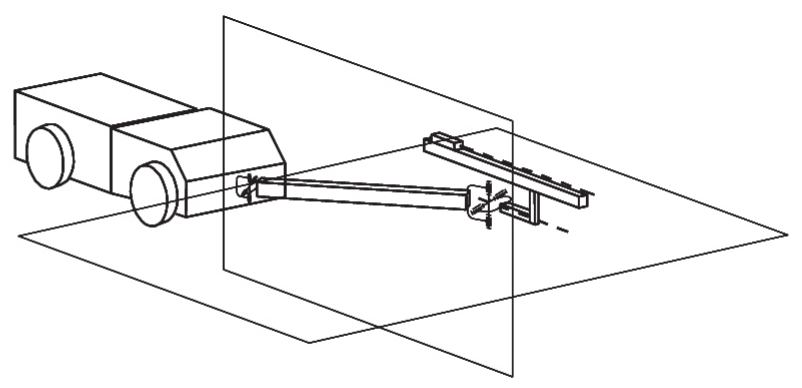

Rys. 2. Wymagane stopnie swobody ramy wiertarki (a) oraz schemat kinematyczny mechanizmu wysiegnika wiertnicy (b) 


\subsection{Omówienie wyników syntezy strukturalnej}

Przedstawiony (rys. 2b) schemat kinematyczny spełnia jedynie warunek żądanych stopni swobody, którymi musi dysponować rama wiertarki. Warunki eksploatacyjne maszyny powodują, że bezpośrednie wymuszenia ruchu w parach obrotowych nie są technicznie możliwe do zrealizowania. Zatem kolejnym etapem syntezy jest zdefiniowanie mechanizmów wymuszających ruch w parach obrotowych, które na wstępnym etapie syntezy traktowane były jako pary czynne. Ze względu na występowanie wysokich wartości momentów przyjęto, że wymuszenia kinematyczne będą realizowane $\mathrm{z}$ wykorzystaniem siłowników hydraulicznych [3].

Umieszczenie punktów mocowania siłownika pomiędzy sąsiadującymi członami połączonymi parą obrotową wymusza konieczność zwiększenia wymiarów gabarytowych krzyży par uniwersalnych. Jest to szczególnie niekorzystne w przypadku pary łączącej wysięgnik z korpusem maszyny, gdzie występują duże siły oddziaływania. Rozwiązaniem tego problemu konstrukcyjnego jest zastosowanie rozsunięcia osi pary uniwersalnej poprzez zastąpienie krzyża odpowiednim członem pośredniczącym. Dodatkową zaletą tego rozwiązania jest fakt, że odległość między osiami jest parametrem, którego wartość można dobierać i dzięki temu wpływać na cechy kinematyczne oraz wytrzymałościowe organu roboczego.

Pełny schemat kinematyczny mechanizmu wysięgnika oraz warunków geometrycznych po uzupełnieniu o człony napędowe przedstawiono na rysunku 3 [3].
W przypadku siłownika odpowiadającego za podnoszenie ramy wiertarki przyjęto inne rozwiązanie niż w pozostałych przypadkach. Jest to spowodowane faktem, że siłownik ten jako jedyny umieszczony jest między sąsiednimi członami tworzącymi parę obrotową. O wyborze takiego rozwiązania zdecydowały względu konstrukcyjne.

Jeśli przyjmiemy współosiowość par A i D, mechanizmy podnoszenia wysięgnika i obrotnika pozostają zawsze w jednej płaszczyźnie. W ruchu płaskim, w celu otrzymania prostowodu, trójkąty $\Delta \mathrm{HBI}$ oraz $\Delta$ MGF muszą zawsze być podobne, a skala podobieństwa jest równa wartości współczynnika hydraulicznego siłowników P1 (HI) i P2 (FM) $-W_{p}$. Wymiary i orientacja tych trójkątów może być dowolna. Pozwala to $\mathrm{w}$ procesie projektowania punktów mocowania siłowników uwzględniać dodatkowe kryteria konstrukcyjne - zmniejszanie naprężeń, odpowiedni dobór kątów przełożenia, unikanie kolizji czy też technologiczność konstrukcji oraz dobór siłowników o znormalizowanych wymiarach. Przy projektowaniu punktów mocowania siłowników należy zwrócić szczególną uwagę na spełnienie warunku podobieństwa dla minimalnej długości rzeczywistych siłowników.

$$
L_{\min P 2} \geq W_{p} \cdot L_{\min P 1}
$$

Niespełnienie warunku (2) skutkuje otrzymaniem rozwiązania teoretycznego lub wymaga specjalnego wykonania siłownika podnoszenia obrotnika P2. Podobnie należy postępować $\mathrm{w}$ przypadku prostowodu skrętu (rys. 4) [3, 4].

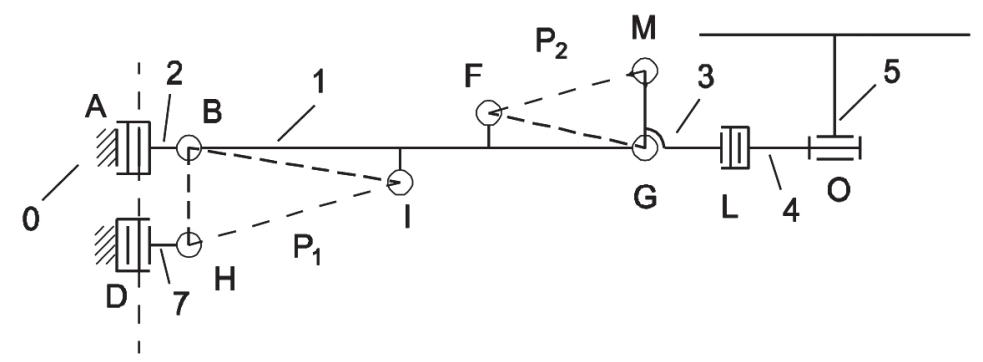

Rys. 3. Schemat kinematyczny mechanizmu oraz warunek otrzymania prostowodu dla podnoszenia wysięgnika wiertnicy FM 1.7 LE

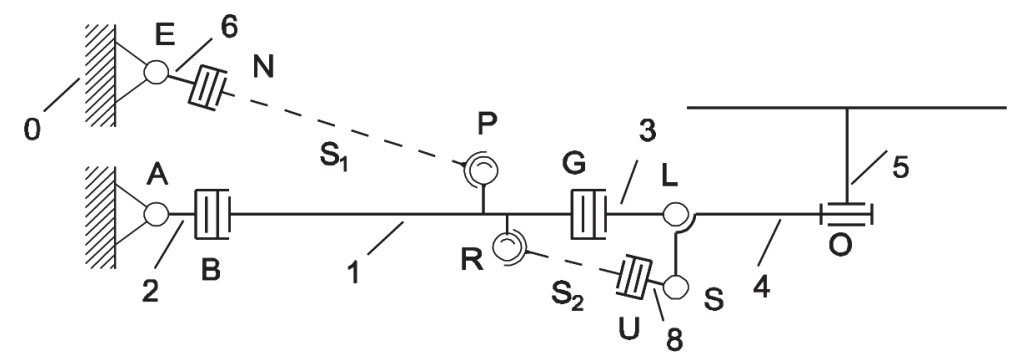

Rys. 4. Schemat prostowodu skrętu (rzut z góry) wysięgnika wiertnicy FM 1.7 LE 
Cechą charakterystyczną mechanizmu skrętu wysięgnika jest to, że podczas podnoszenia wysięgnika (obrót w parze B) następuje jego obrót wokół osi pary A. Zjawisko to występuje przy zachowaniu stałej długości siłownika skrętu S1 (rys. 4). Konsekwencją jego jest brak możliwości utrzymania osi wysięgnika w jednej płaszczyźnie podczas jego podnoszenia. Opisywana sytuacja nie występuje jedynie w konfiguracjach, w których osie par B i N leżą na jednej prostej. Teoretycznie są dwie takie konfiguracje, ale ze względów konstrukcyjnych w przypadku projektowanego mechanizmu skrętu żadna $\mathrm{z}$ nich nie występuje.

Przyczynę, z której powodu podnoszenie wysięgnika nie odbywa się w jednej płaszczýnie w przypadku ustalonej długości siłownika S1, zobrazowano na rysunku 5. Podczas podnoszenia wysięgnika punkt $\mathrm{P}$ znajduje się na trajektorii będącej okręgiem o promieniu BP' i środku leżącym na osi pary B. Zachowanie osi wysięgnika $w$ jednej płaszczyźnie wymaga, aby odległość EP odpowiednio zmieniała się w funkcji kąta podnoszenia wysięgnika $\mathrm{EP}=f\left(\alpha_{p}\right)$. Z drugiej strony odległość EP jest wynikiem stałej długości odcinka EN i siłownika S1. Spełnienie obu tych warunków dla dowolnej stałej wartości kąta skrętu $\alpha_{S}$ nie jest możliwe. Poprzez odpowiedni dobór wymiarów podstawowych można jedynie minimalizować to niekorzystne zjawisko. Analogiczna sytuacja ma miejsce w przypadku mechanizmu odpowiadającego za ruch obrotnika względem wysięgnika.

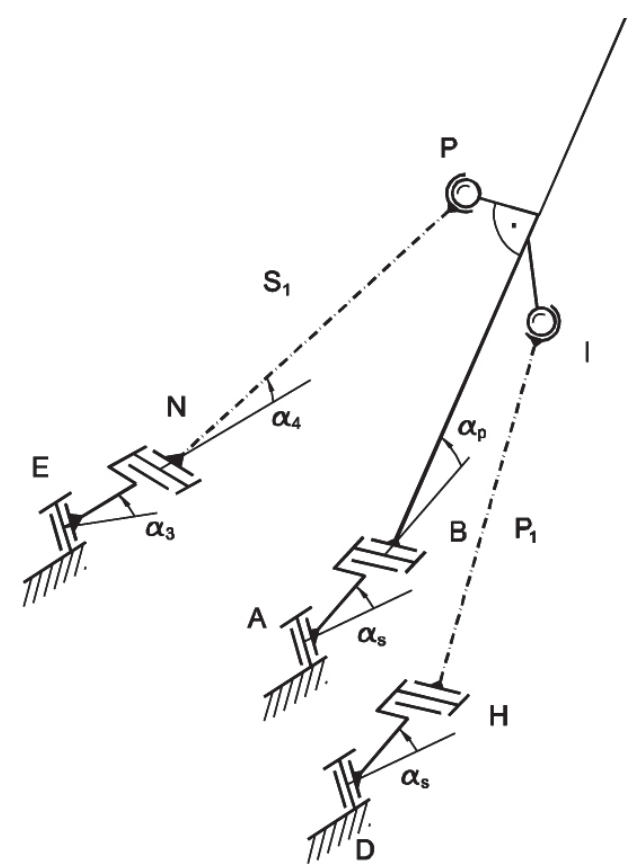

Rys. 5. Przestrzenny schemat kinematyczny mechanizmu podnoszenia i skrętu wysięgnika wiertnicy FM 1.7 LE
Ostatecznie, kierując się kryterium ograniczającym wartości błędów prostowodności i względami konstrukcyjnymi, dobrano punkty mocowania siłowników skrętu wysięgnika, obrotnika oraz przyjęto pozostałe wymiary prostowodu skrętu. W procesie tym szczególną uwagę zwracano na to, aby układ kinematyczny nie osiągał konfiguracji osobliwych.

Określone powyżej parametry geometryczne wiertnicy FM 1.7 LE spełniają wszystkie narzucone parametry i założenia projektowe. Jak wykazano, stworzone prostowody skrętu i podnoszenia nie są ze względu na przyjęte ograniczenia techniczne układami idealnymi i mogą wnosić podczas ruchu w założonym polu pracy pewne błędy prostowodności $\Delta y$ i $\Delta \mathrm{z}$ mierzone $\mathrm{w}$ płaszczyznach skrętu i podnoszenia. W związku z tym wyznaczone parametry geometryczne zostały zweryfikowane podczas numerycznych badań symulacyjnych w systemie do analizy dynamicznej układów wieloczłonowych typu MSC Adams czy LMS DADS.

\section{BADANIA SYMULACYJNE}

Na potrzeby dalszych badań, dla opracowanej kinematyki organu roboczego projektowanego wozu wiercącego FM 1.7 LE, został zbudowany pełny model symulacyjny ze zdefiniowanymi siłownikami skrętu i podnoszenia wysięgnika, pracującymi w układach prostowodów (rys. 6) [3]. Do przeprowadzenia badań symulacyjnych wybrano system LMS DADS. Model ten posłużył do badania układu pod kątem występowania położeń osobliwych oraz do analizy błędów $\Delta y$ i $\Delta z$ prostowodności oraz do określenia dokładnych granic pola pracy wiertnicy.

Człony mechanizmów podczas pracy mogą przyjmować położenia nieokreślone kinematycznie. Takie pozycje mechanizmu nazywa się powszechnie bądź konfiguracjami osobliwymi, bądź położeniami osobliwymi. Konfiguracja osobliwa układu mechanicznego to taka, w której zachowania systemu nie można przewidzieć (nie można wyznaczyć). Układ doprowadzony do położenia osobliwego zmienia swoje właściwości dynamiczne i kinematyczne (ruch przestaje być kontrolowany). Wartości niektórych parametrów (sił, prędkości i przyspieszeń) stają się nieokreślone bądź dążą do nieskończoności. Pochodne równań więzów układu mechanicznego w takim położeniu wykazują matematyczną osobliwość, nie mają rozwiązania. 
a)

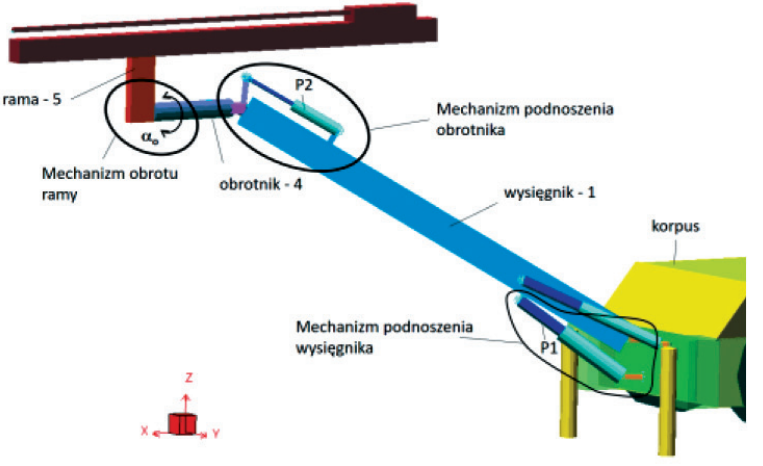

b)

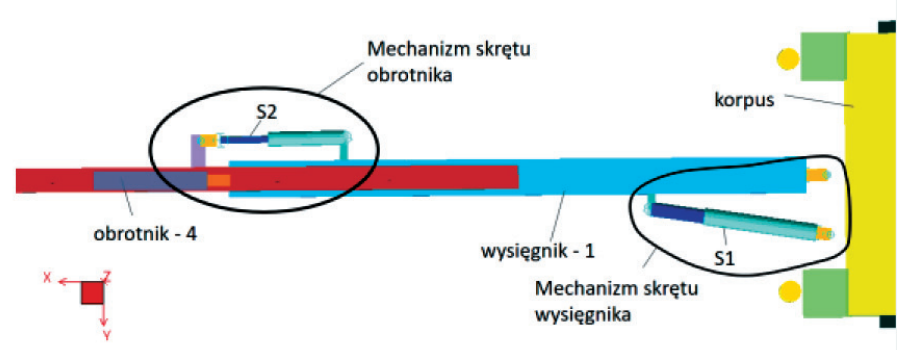

Rys. 6. Widok modelu bryłowego wiertnicy FM 1.7 LE: a) mechanizmy: podnoszenia wysięnika, podnoszenia obrotnika i obrotu ramy; b) widok z góry modelu z zaznaczonymi mechanizmami: skrętu wysięgnika i skrętu obrotnika

W pobliżu konfiguracji osobliwej małe zmiany parametrów wejściowych (prędkości, sił) mogą przynieść duże zmiany parametrów wyjściowych (bądź odwrotnie). W niektórych przypadkach zajęcie przez człony mechanizmu położeń osobliwych ze względu na znaczny wzrost sił może doprowadzić do zniszczenia lub uszkodzenia układu. Podczas projektowania powinno się bezwzględnie uwzględnić położenia osobliwe i nie dopuszczać układu do przyjmowania takich konfiguracji. Stąd jednym z szeroko rozważnych i istotnych problemów projektowania jest wyznaczanie konfiguracji mechanizmów oraz analiza zachowania mechanizmów w położeniach osobliwych. W opracowanym układzie kinematycznym tak dobrano wymiary członów oraz napędów, aby dla kinematy- ki zapewniającej osiągnięcie zdefiniowanego pola pracy nie występowały położenia osobliwe.

\subsection{Wybrane wyniki badań symulacyjnych}

Badania symulacyjne układu pozwalają przede wszystkim na określenie rzeczywistych zakresów ruchów wiertnicy i w konsekwencji na określenie rzeczywistego pola pracy. Parametrami wymuszającymi ruchy układu były wydłużenia i skrócenia siłowników $\mathrm{P}_{1}, \mathrm{P}_{2}, \mathrm{~S}_{1}$ i $\mathrm{S}_{2}$ pracujących w układzie prostowodu hydraulicznego. Badania symulacyjne wysięgnika przeprowadzono dla pracy $\mathrm{z}$ maksymalnie wysuniętym wysięgnikiem. Osiągnięte pole pracy przedstawiono na rysunku 7.

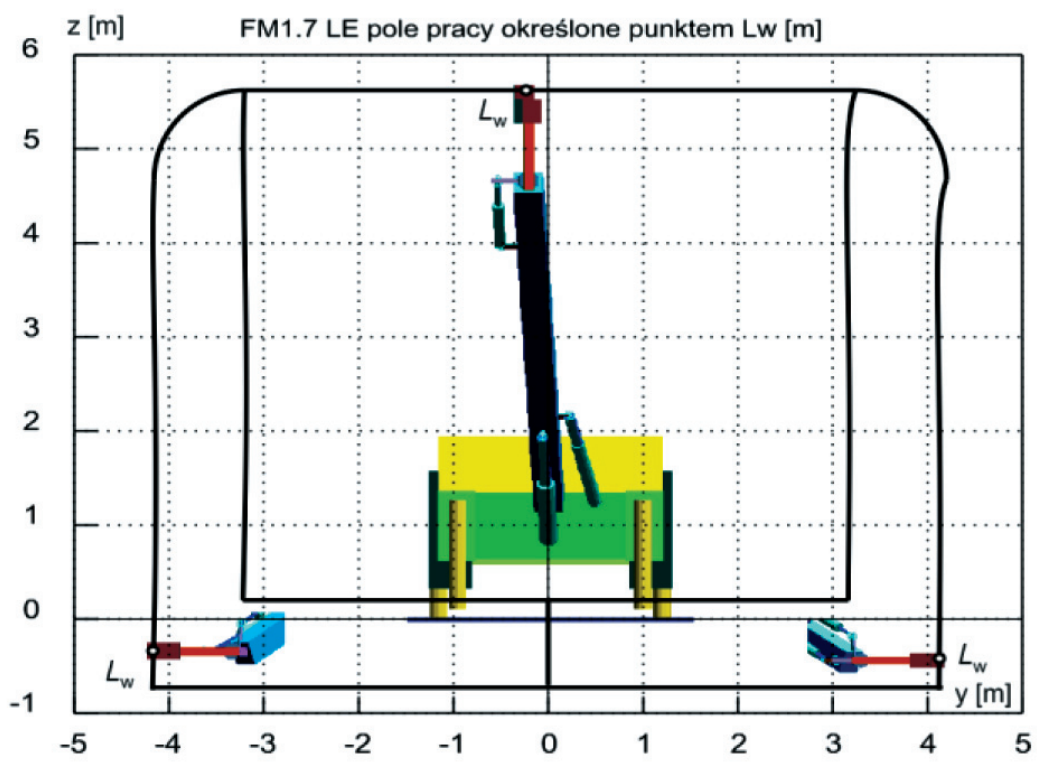

Rys. 7. Łączne pole pracy wiertnicy FM 1.7 LE określone przez punkt $L_{w}$ na ramie osiagnięte $z$ trzema położeniami wiertarki: pionowym (kąt obrotu obrotnika $\alpha_{o}=0^{\circ}$ ) i poziomym dla kątów obrotu obrotnika $\alpha_{o}=90^{\circ} i \alpha_{o}=-90^{\circ}$ 
Ponadto przeprowadzono analizy błędów, dokonując symulacji przemieszczeń wysięgnika po wybranych liniach na polu pracy. Na rysunku 8 przedstawiono pole pracy ze schematem przebadanych linii: p-25, p0, p15, p30, p45, s-38, s-19, s0, s19, s38. Dodatkowo na polu pracy wyznaczono punkty pomiaro- we $P_{\mathrm{ij}}(i=0, \ldots, 5 ; j=1, \ldots, 7)$, dla których wyznaczono dokładne wartości błędów.

Na rysunku 9 zamieszczono przykładowy schemat symulacji oraz przebiegi wyznaczonych błędów: $\Delta y-$ prostowodu skrętu, $\Delta z$ - prostowodu podnoszenia, dla ruchu po wybranej linii poziomej.

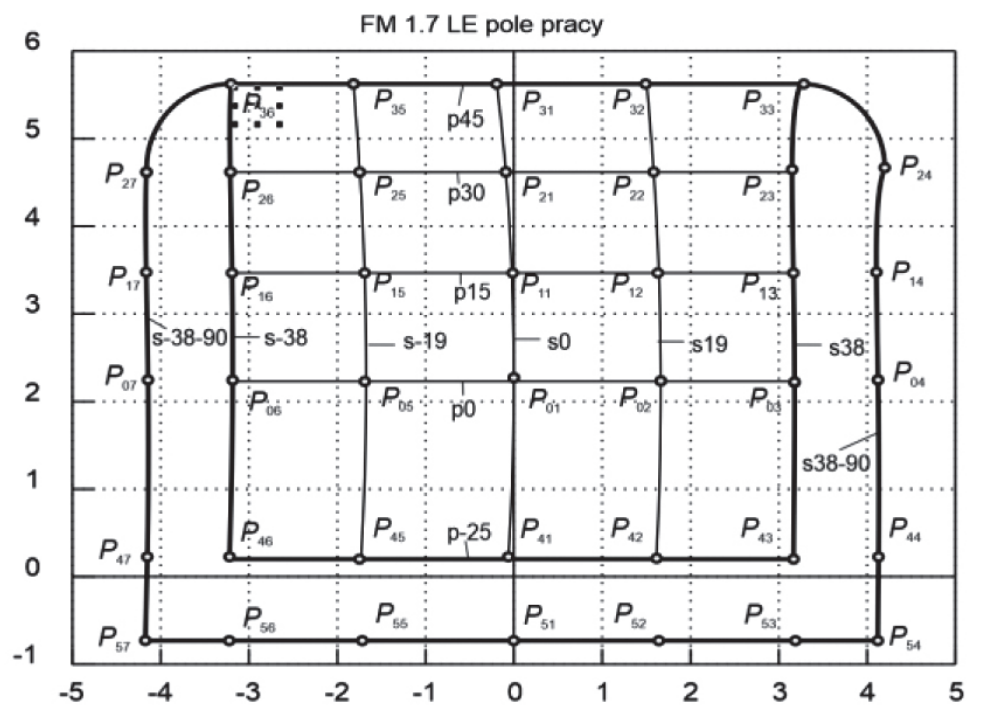

Rys. 8. Widok z przodu pola pracy wiertnicy FM 1.7 LE z wyspecyfikowanymi liniami badań i punktami $P_{i j}$, w których określono szczegółowo wartości błędów prostowodu podnoszenia $\Delta z$ i skrętu $\Delta y$

a)

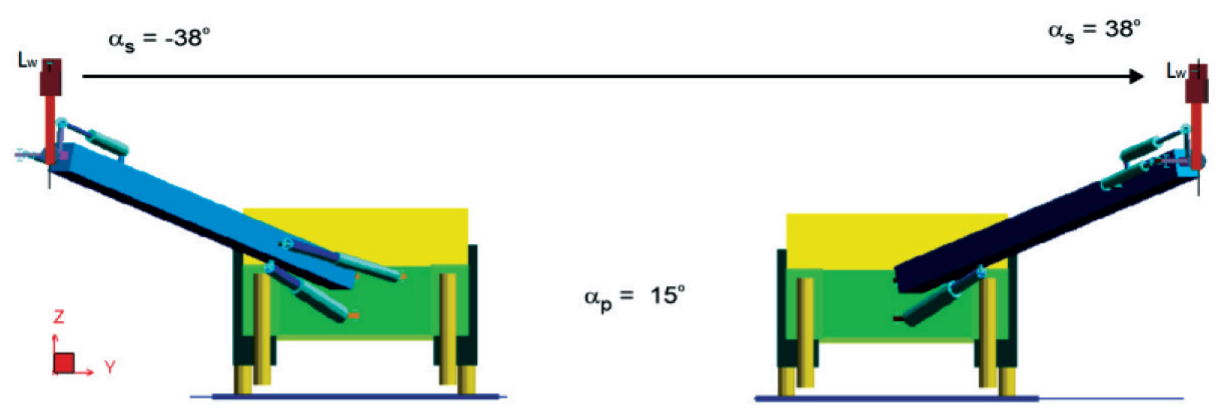

b)

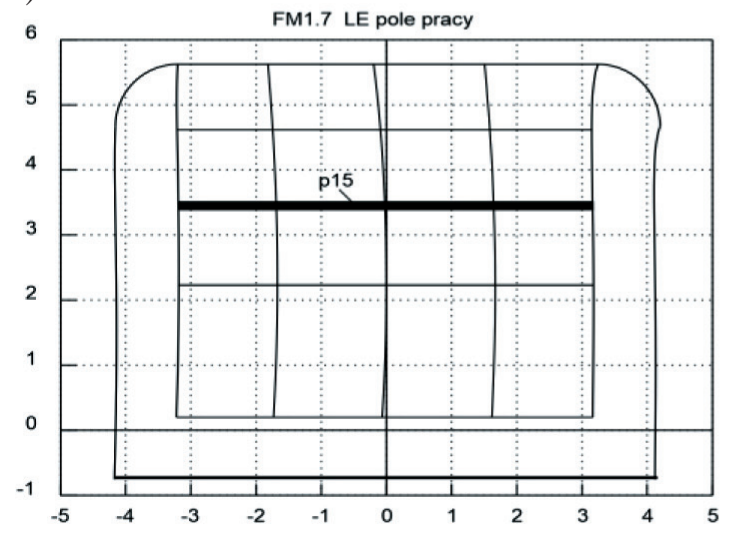

c)

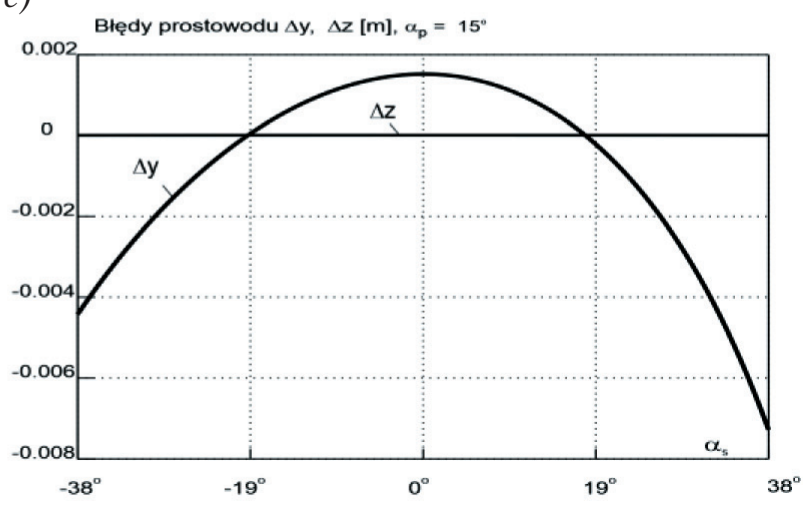

Rys. 9. Badania dokładności prostowodów ramy wiertarki podczas przemieszczania ramy (punkt $L_{w}$ ) wzdłuz linii p-15 $w$ funkcji kąta skrętu $\alpha_{s}\left(-38^{\circ}<\alpha_{s}<38^{\circ}\right.$ - zmieniany wysuw siłownika skrętu przy stałym kacie podnoszenia $\alpha_{p}=-25^{\circ}$, stały wysuw siłownika podnoszenia): a) schemat symulacji; b) położenie prostej p-15; c) uzyskane przebiegi błędów $\Delta z$ prostowodu podnoszenia i $\Delta y$ prostowodu skrętu 


\section{WNIOSKI}

W wyniku przeprowadzonych prac opracowano strukturę, kinematykę i geometrię układu roboczego nowego wozu wiercącego o napędzie bateryjnym typu Face Master 1.7 LE dla zadanego pola pracy $(\mathrm{H} \times \mathrm{W}$ $-5,6 \times 8,4 \mathrm{~m})$ oraz kątów podnoszenia i skrętu wysięgnika.

W pierwszej części pracy przeprowadzono syntezę strukturalną mechanizmu wysięgnika, której celem było zapewnienie wiertarce wymaganych stopni swobody. Wynikiem był wybór schematu podstawowego wysięgnika, który daje możliwość pracy wiertnicy zarówno przy sprzężeniu kinematycznym odpowiednich par członów czynnych, jak i na całkowicie niezależne ich działanie. W kolejnym etapie wybrano schemat kinematyczny wysięgnika, który następnie został uzupełniony łańcuchami zawierającymi człony czynne (siłowniki). Dysponując już pełnym schematem kinematycznym, przystapiono do zdefiniowania jego wymiarów podstawowych. Przy projektowaniu geometrii układu kinematycznego wysięgnika zostały uwzględnione wszystkie narzucone założenia i ograniczenia projektowe (m.in. maksymalne zakresy ruchu, rodzaj i geometria siłowników, współczynniki hydrauliczne prostowodów, wymiary płyty mocującej, typ i geometria ramy wiertarki, obrotnik itp.).

Proces ustalania wymiarów podstawowych został podzielony na dwie fazy. W pierwszej zdefiniowano geometrię mechanizmu podnoszenia. W kolejnym kroku dobrano wymiary mechanizmu skrętu. Proces definiowania wymiarów podstawowych realizowany był przy założeniu, że głównym zadaniem wiertnicy jest jej praca w układzie sprzężenia hydraulicznego.

Nadrzędnym kryterium jakości działania projektowanego układu prostowodu wysięgnika było zachowanie stałej orientacji osi wiertła w każdym punkcie pola pracy. Niestety, spełnienie wymagań konstrukcyjnych pociągało za sobą konieczność pogorszenia jakości uzyskanego prostowodu. $\mathrm{Z}$ tego powodu konieczny był żmudny proces projektowania wymiarów układu kinematycznego, którego celem było uzyskanie błędów prostowodności osi wiertła poniżej $1^{\circ}$.

Wynikiem przeprowadzonych prac jest układ kinematyczny wiertnicy FM 1.7 LE, który osiąga wymagane pole pracy wiertarki o wysokości H i szerokości W).

\section{Podziękowania}

Badania wspólfinansowane przez Narodowe Centrum Badań i Rozwoju w ramach projektu „Nowa generacja modułowych maszyn, wiercącej i kotwiącej, $\mathrm{z}$ napędami bateryjnymi, przeznaczonych do pracy w podziemnych kopalniach rud miedzi i surowców mineralnych”, nr umowy POIR.01.01.01-00-D011/16 w Programie Operacyjnym Inteligentny Rozwój.

\section{Literatura}

[1] Butra J., Dębkowski R., Kosiorowski A., Kosior A.: Sposób wybierania złoża o małej miąższości w strefach ochronnych głównych wyrobisk korytarzowych kopalń rud miedzi, „Rudy i Metale Nieżelazne" 2004, 49, 6: 272-279.

[2] Grzesiński J.: Doświadczenia kopalni „Lubin” w prowadzeniu eksploatacji $w$ warunkach skrępowanych na przyktadzie wybranych filarów oporowych, ,Mechanizacja i Automatyzacja Górnictwa" 2007, 9: 46-58.

[3] Bałchanowski K.J., Wudarczyk S., Karliński J.: Opracowanie oraz analiza kinematyki układów roboczych samojezdnych maszyn górniczych o napędzie bateryjnym, „Raporty Wydziału Mechanicznego Politechniki Wrocławskiej” 2017, 100: 77.

[4] Bałchanowski K.J., Szrek J., Wudarczyk S.: Kinematic aspects of the drilling ring boom design, $\mathrm{w}$ : Proceedings of the 22nd International Scientific Conference, Kaunas 2017: 27-31.

dr inż. JACEK KARLIŃSKI

mgr inż. PAULINA DZIAEAK

Katedra Konstrukcji i Badań Maszyn

dr hab. inż. KRZYSZTOF JACEK BAŁCHANOWSKI

dr inż. SEAWOMIR WUDARCZYK

Katedra Inżynierii Biomedycznej, Mechatroniki

i Teorii Mechanizmów

Wydziat Mechaniczny

Politechnika Wrocławska

ul. Łukasiewicza 7/9, 50-371 Wroctaw

\{jacek.karlinski, paulina.dzialak, jacek.balchanowski, slawomir.wudarczyk\}@pwr.wroc.pl 